KALAM, P-ISSN: 0853-9510, E-ISSN: 2540-7759

http://ejournal.radenintan.ac.id/index.php/kalam

DOI: http://dx.doi.org/10.24042/klm.v13i2.4548

Volume 13, Number 2, December 2019, p. 143-166

\title{
Cosmological Dimensions in The Teachings of The Naqshabandi Sufi Order
}

\section{Nunu Burhanuddin}

Faculty of Ushuluddin, Adab and Dakwah, IAIN Bukittinggi, Indonesia nunu.burhanuddin@iainbukittinggi.ac.id

\section{Usman Syihab}

Faculty of Islamic Studies, UIN Starif Hidayatullah Jakarta, Indonesia usmansyihab@uinjkt.ac.id

\begin{abstract}
In general, studies about tariqa have put more emphasis on aspects related to ritual teachings and spiritual experience of the Sufi leaders. Little has been studied so far about how teachings of a Sufi order are related to cosmological concepts. This paper aims to analyze the cosmological concepts that are taught in the teachings of the Naqshbandi Sufi order in the district of Pauh, the city of Padang, West Sumatera. Data for this research are gathered through interviews, observation and documentation. These data are then analyzed with content analysis method. The research find that the Naqshbandi order perceives the notion of sharia as one that is intimately related with divine revelation and the universe's law of order, a holistic approach that regards deeds of a sālik (a Sufi traveler) as part of the cosmic order. The existing seven types of sharia law outline seven layers of heaven and earth. Thus, a mystic attainment of martabah hakikat (degree of reality) represents seven layers of heaven and earth, which are manifested through amaliah lathäif (inner 'worship' rituals) - all of which are attributed to internal parts of the human soul, such as brain, heart, spleen, liver, lungs and all internal parts of the human physical body. Within the Naqshbandi Sufi order, all sâlik aredevised to be able to attain close relationship with God, and to become an imagery of human's mystical potentials in their everyday lives' activities.
\end{abstract}

Keywords : Cosmological Dimensions, Naqshabandi, Sufi Order, Sālik 
Abstrak : Secara umum, studi tentang tariqa telah lebih menekankan pada aspekaspek yang berkaitan dengan ajaran ritual dan pengalaman spiritual para pemimpin Sufi. Sejauh ini sedikit yang telah dipelajari tentang bagaimana ajaran sufi terkait dengan konsep-konsep kosmologis. Makalah ini bertujuan untuk menganalisis konsep-konsep kosmologis yang diajarkan dalam ajaran tarekat Sufi Naqshbandi di kabupaten Pauh, kota Padang, Sumatera Barat. Data penelitian dikumpulkan melalui wawancara, observasi dan dokumentasi. Data-data ini kemudian dianalisis dengan metode analisis isi. Penelitian ini menemukan bahwa ajaran Naqsybandi memandang gagasan syariah sebagai sesuatu yang terkait erat dengan wahyu ilahi dan hukum alam semesta, suatu pendekatan holistik yang menganggap perbuatan seorang sālik (pengembara sufi) sebagai bagian dari tatanan kosmik. Tujuh jenis hukum syariah yang ada menguraikan tujuh lapisan langit dan bumi. Dengan demikian, pencapaian mistik dari martabah hakikat (tingkat realitas) mewakili tujuh lapisan langit dan bumi, yang dimanifestasikan melalui amaliah lathāif (ritual 'penyembahan' batin) - yang semuanya dikaitkan dengan bagian internal jiwa manusia, seperti otak, jantung, limpa, hati, paru-paru dan semua bagian internal tubuh fisik manusia. Dalam tatanan Sufi Naqshbandi, semua sālik direvisi untuk dapat mencapai hubungan yang dekat dengan Tuhan, dan untuk menjadi gambaran potensi mistis manusia dalam kegiatan kehidupan sehari-hari mereka.

Kata Kunci : Dimensi Kosmologis, Naqshabandi, Tarekat, Sālik

\section{A. Introduction}

As the biggest Sufi order in Indonesia, Tarekat Naqsyabandiyah (or, the Naqshabandi order) is widely practiced in various regions of the country, including in West Sumatra. The popularity of the Naqshbandi order has led many researchers to study its teachings, religious practices, and historical development. Yet, little has been studied so far about how teachings of the Naqshbandi order are related to cosmological concepts.

One of the most representative studies about the Naqshbandi order in Indonesia is Martin van Bruinessen's Tarekat Naqsyabandiyah di Indonesia. In his book, van Bruinessen was able to explain the teachings and rituals of the Naqshbandi order in Indonesia, and to trace its origin. He also managed to show the development of the Naqshbandi across several islands of the archipelago, including Riau, Kalimantan, Sumatra, Java, Madura, 
Sulawesi and Lombok. ${ }^{1}$ Other studies on the Naqshbandi include the works by Susanto, ${ }^{2}$ A. Fuad Said, ${ }^{3}$ Moh Taufik, ${ }^{4}$ Baharudin, ${ }^{5}$ Sakir, ${ }^{6}$ Wahyuddin, ${ }^{7}$ Firdaus, ${ }^{8}$ Duski Samad, ${ }^{9}$ Syarif, ${ }^{10}$ Ashma Rimadany, ${ }^{11}$ Adlan Sanur Tarihoran, ${ }^{12}$ and others. As for studies on the Naqsyabandi order in Padang, they can be found in the writings of Yulizal Yunus, ${ }^{13}$ Afnida Nengsih, ${ }^{14}$ and

${ }^{1}$ Martin Van Bruinessen, Tarekat Naqsyabandiyah di Indonesia (Bandung: Mizan, 1992).

${ }^{2}$ Faisal Bahar Susanto, “Tareqat Qadiriyah Naqshabandiyah: Tinjauan Historis dan Educatif Tarekat Qadiriyah Naqshabandiyah di Desa Balak” (Ph.D Thesis, Surakarta, Universitas Muhammadiyah Surakarta, 2006).

${ }^{3}$ Fuad Said, Hakekat Tarekat Naqshabandiyah (Jakarta: Pustaka al-Husna, 1994).

${ }^{4}$ Moh. Taufiq, "Pola Pendidikan Berbasis Tareqat Qadiriyah wa Naqshabandiyah di Pondok Pesantren Assalafi al-Fitrah Surabaya," Jurnal Pendidikan Agama Islam VOl. 5, no. 1 (2017): 138-60.

5 Burhanuddin dan Nur Latifah, "Peran Pendidikan Tarekat Qadiriyah wa Naqsyabandiyah,” Jurnal Tatsqif Vol. 15, no. 2 (2017): 223-41.

6 Moh. Sakir, "Genealogi Tarekat Pesantren Sebagai Basis Pembentukan Kesalehan,” Manarul Qur'an: Jurnal Ilmiah Studi Islam Vol. 18, no. 2 (2018): 64-79.

7 Dedy Wahyudin, "Memahami Bahasa Sufistik Kaum Salikin: Studi Kasus Pengamal Tarekat Qadiriyah Wa Naqsyabandiyah di Pondok Pesantren Darussalam Bermi Lombok Barat Nusa Tenggara Barat," El-Tsaqafah: Jurnal Jurusan PBA Vol. 15, no. 2 (2016): 113-23.

${ }^{8}$ Firdaus dan et.al, Sentra-Sentra Tarekat di Minangkabau, 2000.

${ }^{9}$ Duski Samad, "Tradisionalisme Islam di Tengah Modernisme: Kajian Tentang Kontiniutas, Perubahan dan Dinamika Tarekat di Minangkabau" (Disertation, Jakarta, UIN Syarif Hidayatullah Jakarta, 2003).

${ }^{10}$ Syarif, "Dari Masīrat al-Hikam Hingga Kayfiyat al-Ṭarīqat: Pergeseran Ajaran tarekat Naqshabandiyah di Sumatera Barat,” PENAMAS Vol. 28, no. 1 (2015).

11 Ashma Rimadany, "Comparative Study Between Naqsabandiyah and Syattariyah Congregations in Determining the Beginning of Islamic Lunar Month in West Sumatera Province" (Thesis, Semarang, UIN Walisongo, 2016).

${ }^{12}$ Adlan Sanur Tarihoran, "Maliek Bulan Sebuah Tradisi Lokal Pengikut Tarekat Syattariyah di Koto Tuo Agam," ISLAM REALITAS: Journal of Islamic and Social Studies Vol. 1, no. 1 (2015), 10.

13 Yulizal Yunus, “Kajian Syair Apolegetik Pembela Tarekat Naqsyabandiyah Syaikh Bayang” (Research, Padang, IAIN Imam Bonjol, 1999).

${ }^{14}$ Afnida Nengsih, "Amalan Pengikut Tarekat Naqshabandiyah di Kecamatan Pauh Padang” (Research, Padang, IAIN Imam Bonjol, 1998). 
Zainal Abidin..$^{15}$ Most of these studies discuss the ritual teachings, their implementation, and the historical dimension of the Naqshbandi order in Padang. Thus, there has been no research that studies the relationship between the Sufi teachings and issues of cosmology

This article aims to explore the cosmological dimension that is embedded in the teachings of the Naqshabandi order in Pauh, Padang, West Sumatera. It is believed that this Sufi order has introduced new ways of understanding cosmology as a conception of both sharia and haqiqa (the divine reality) teachings. The significance of this study is to provide a new spirit of scientific development among observers of tasawuf(mysticism) and tariqa (Sufi order), who have so far paid more attention on aspects of practicality in Sufism. As a scientific study, this article will use a content analysis method, toward verbal statements delivered by the Naqshbandi Sufi figures in Pauh, the city of Padang, on occasions of religious forums, or during the interviews with the authors. In addition, relevant books are also consulted to gain further understanding about the studied issues.

\section{B. General Overview About Cosmology}

Cosmology comes from the Greek words, "cosmos" (composition or arrangement) and "logos" (science), and is the antonym of "chaos", which means "chaotic." ${ }^{16}$ Despite the word "logos" also means "order", "cosmology" is more precisely interpreted as rational principles. ${ }^{17}$ The term cosmology was first popularized by Christian von Wolff in his book "Discourses Praeliminaris de Philosophia in Genere" in 1728, categorizing it as a branch of "metaphysics", and distinguishing it from other metaphysical branches, such as "ontology",18 "metaphysical theology", or "metaphysical psychology." ${ }^{\text {"19 }}$ Here cosmology is understood as a branch of philosophy that discusses about the origin and the order of the universe; thus different from "ontology" or "general metaphysics" which is a study of the general

15 Zainal Abidin, "Membangun Harmoni Lewat Kebersamaan: Studi Kasus Dampak Sosial Penentuan Awal Ramadhan dan 1 Syawal Terhadap Umat Islam di Kota Padang," Harmoni Vol. 9, no. 1 (2012): 56-66.

${ }^{16}$ Anton Bakker, Metodologi Penelitian Filsafat(Yogyakarta: Kanisius, 1995): 39.

${ }^{17}$ Louis Kattsoff, Pengantar Filsafat (Yogyakarta: Tiara Wacana, 1986): 75.

${ }^{18}$ Runes D. Dagobert, Dictionary of Philosophy (Tottawa: Litle Field Adams \& Co., 1977): 65.

${ }^{19}$ Paul Edward, The encyclopedia of philosophy, vol. 2 (New York, 1967): 7. 
characteristics of the natural and supernatural reality. Cosmology is also distinguished from the "philosophy of nature", which investigates the basic laws, processes and classifications of objects in nature. Yet, the term "cosmology" is also used within the scope of empirical science, or the science that combines the results of astronomical observations with theories of physics in order to construct the physical things of the universe in a unity with a large scale. Considering its variety of meanings, the term cosmology in this paper is designed to refer to the study of the structure and history of a large-scale universe, that can be understood from the perspective of astronomy, philosophy and religion. In this context, Jonathan Keohane divides cosmology into several parts, namely physical cosmology, philosophical cosmology and religious cosmology. Physical cosmology includes several studies such as big bang, ${ }^{20}$ dark matter, ${ }^{21}$ dark energy, ${ }^{22}$ and cosmic inflation. ${ }^{23}$

The philosophical cosmology is concerned with contingency, (the necessity that refers to the law), the certainty and immortality, the boundaries and the formal laws of the world, the freedom of human and the origin of human, and the origin of evil. In this regard, the philosophers are more concerned with the nature and relationship between space and time, and with the question of freedom and the origin of human evil outside the field of cosmology itself. ${ }^{24}$ Systematically, philosophical cosmology is distinguished by four variants, namely (1.) rests on the ontical belief that the nature of the world is plural or singular, (2.) the human position in the cosmic (subjectivist, objectivistic); (3.) human essence and substance with other essence and substance of the world; and (4.) synthesis approach. ${ }^{25}$

${ }^{20}$ E. L. Wright, What is The Evidence for The Big Bang? (UCLA: Devision of Astronomy and Astrophysics, 2009).

21 Jonathan Keohane, "Bing Bang, Nasa's Imagine the Universe: Ask an Astrophysicist," t.t., accessed 3 September 2017.

${ }^{22}$ Sean M. Carroll, Dark Matter, Dark Energy: The Dark Side of the Universe, Part $1 \& 2$ (The Teaching Company, 2007): 48.

${ }^{23}$ Katsuhiko Sato, "First-order phase transition of a vacuum and the expansion of the Universe," Monthly Notices of the Royal Astronomical Society 195, no. 3 (1981): 46779.

${ }^{24}$ Runes D. Dagobert, Dictionary of Philosophy (Tottawa: Litle Field Adams \& Co., 1977): 69.

${ }^{25}$ Anton Bakker, Metodologi Penelitian Filsafat(Yogyakarta: Kanisius, 1995): 38. 
Then, the cosmology of religion or also called mythology is a way to explain the origin, history and evolution of the cosmos based on the religious mythology of a specific tradition. The view of religious cosmology can be seen from the perspective of the Bible, the holy book of the Qur'an, the traditions of Buddhism, Hinduism, Jainism, and others. In the Bible tradition, it is mentioned that the universe is made of a ground-shaped earth of a ground disk that floats on water with heaven above it and the underworld below it. At the time of human lives on the earth during his lifetime and in the the underworld after his death. ${ }^{26}$ In the tradition of Buddhism, cosmology or the creation and maintenance of the universe is an important doctrine in dharma. In Buddhism, the cosmos or called loka is divided into three great realms, namely sankharaloka (inanimate), sattaloka (living creature), and okasaloka (media of inanimate objects). ${ }^{27}$ In the Hindu tradition, it is mentioned that the creation of nature occurred after Mahapralaya, the melting of the universe, the complete darkness. All is in a state of sleep, no matter what, either movable or immovable. Then Svayambhu (self being) incarnated, which is a form outside the senses. It created water, the first liquid that creates the seed of creation in it. The seed grew into a golden egg. Then Svayambhu entered the egg and was called Visnu, and so on until it formed the universe. The golden egg, as mentioned in Vayu Purana 4: 72-73, is the place where the universe including the moon, the sun, the galaxy and the planets is in it. From that golden egg, it is also created the matter of nature. ${ }^{28}$

Later, in Islamic teachings, the Qur'an provides information about the creation, structure and evolution of the universe as a sign to contemplatively remember the power of Allah (or tadabbur,) (QS. Ali Imran: 190-191). From the practice of tadabbur, the Qur'an establishes a noble Muslim character, which is called, ulil albab (the contemplative man). This character refers to (i) those who always remember Allah while standing, sitting, or lying down; (ii) always think about the creation of the

\footnotetext{
${ }^{26}$ J. Edward Wright, The Early History of Heaven (USA: Oxford University Press, 2002): 117-24.

27 I Gusti Made Widya Sena, "Konsep Kosmologi Dalam Perspektif Agama Budha," Vidya Samhita Jurnal Penelitian 110, no. 1 (2015): 110-24.

28 "Konsep Penciptaan Alam Semesta Menurut Hindu, Islam, Kristen Dan

Konsep Modern," Because of You (blog), 30 April 2009, https://www.narayanasmrti.com/2009 /04/konsep-penciptaan-alam-semesta-hinduislam-kristen-dan-secara-ilmiah/.
} 
heavens and the earth, relentlessly studying natural phenomena; (iii) always think that God has not created all in the universe in vain; and (iv). always realize that while their intellectual odyssey may be misguided, they are always pleading with Allah.

The Qur'an also explains the concept of the universe. It confirms to the unbelievers who still do not want to believe that between heaven and earth is a unified cosmos, then Allah separates the two. And from the water, Allah makes everything that lives, the Qur'an declares the universe comes from a single source of matter and energy, and then Allah develops it. The Qur'an clearly states that the universe is expanding, and is dynamic with all its consequences. The concept of expanding universe is one of the fundamental concepts in modern cosmology. Such an expansion of the universe is proved by Allah by His signs of creating the heavens and the earth and the creeping creatures that He spreads on them. And He collects them when He will (QS. Al-Syurā: 29; Al-Qiyāmah: 8-9).

\section{Profile of The Naqshabandi Order in Padang}

West Sumatra is a province that has a relatively large number of Naqshabandi congregations. This Sufi order, first appearing in West Sumatra in $1850 \mathrm{AD}$, was brought by Syeikh Isma'il from Sinabur, and later was spread by his disciples such as Sheikh Tuanku Berulak (Muhammad Thahir from Berulak in Nagari Padang Gantiang, Tanah Datar), who died in the mid-1860. ${ }^{29}$ Over time, teachings of the Naqshabandi order have spread rapidly in West Sumatra. Some of the old surau (a prayer house) that are respected by the community become centers of Naqshabandi teachings such as in Silungkang (Cangking, Ampek Angkek, Agam), Pasia (Agam), Kasih (Singkarak) and in Bonjol. One of the most famous and influential Sufi masters was Syeikh Jalal al-Din from Cangking. He preached many Minang people to become the Naqshabandi followers, and this caused him to engage in conflicts with the teachers of the Syathariyah and other smaller local Sufi orders, by virtue of the putative threat that the former bring into the latter. ${ }^{30}$

The Naqshbandi leader, Sheikh Jalaluddin, has introduced a number reforms. These include total termination with local traditions and re-orientation to Mecca, rejection of syncretic mysticism and shirk,

\footnotetext{
${ }^{29}$ Bruinessen, Tarekat Naqsyabandiyah di Indonesia.

${ }^{30}$ Ibid. 126.
} 
emphasis on the need to pronounce Arabic correctly, aligning the Qibla direction of the mosque, and determining the beginning and end of Ramadhan. After he died, the order was then led by Sheikh Ibrahim bin Pahad - died in $1915 \mathrm{AD}$ in his age of over a hundred years. ${ }^{31}$

The development of the Naqshabandi order in Padang began in 1906 AD. It was brought by Syeikh Muhammad Thaib (1870-1944 AD), a resident of Pasar Baru in Padang, who had studied for a long time in Mecca. After returning from Mecca in 1905 AD, Sheikh Muhammad Thaib developed the teachings of the Naqshabandi in Padang. He approached the local people in a friendly manner, so that his doctrines were quickly accepted by the people. In $1911 \mathrm{AD}$, he built a surau which was used as a place to teach the doctrines of the Naqshabandi. The surau, which is known as Surau Baru and Baitul Makmur, still exists until now. The spiritual activities of the Naqshabandi such as suluk, wirid, tawajjuh and religious lectures are still practiced in the surau. ${ }^{32}$

Since its establishment, the Naqshabandi has undergone a rapid growth and its followers come from various regions in the archipelago. They studied to Sheikh Muhammad Thaib or to his disciples namely Sheikh Munir and Syafri Malin Mudo. His followers came from Indarung, MungkoMungko (Solok), Kapalo Koto and some areas around the city of Padang and West Sumatra. After they completed their compulsory education, they will be granted a diploma from the mursyid, or the syaikh, as a sign of their graduation. The diploma gives them an opportunityor authority to spread the teachings of the Naqshabandi. This accelerated the dissemination of the teachings of the Naqshabandi in West Sumatra, among others in Indarung, Pasar Baru, Kapalo Koto, Bandar Buat, Kampung Jambak, Simpang Gaduik, Cangkeh, Duku, Baringin, Tarantang, Lubuak Sarik, Kampuang Jua, Pesisir Selatan and Solok. After Sheikh Muhammad Thaib died, the leadership of Naqshabandi Tariqat was continued by his nephew, Sheikh Angku Munir. After Sheikh Angku Munir died, he was replaced by his nephew Munyar Magek. Now the order is led by Syafri Malin Mudo. In 1990, Syafri Malin Mudo built Surau Baitul Makmur as the spiritual activity center of the Naqshabandi. His followers are very solid and loyal. ${ }^{33}$

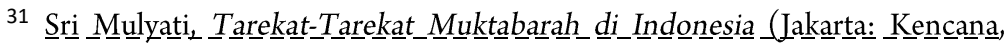

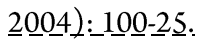

${ }^{32}$ Syafri Malin Mudo, Interview, 19 Juni 2017.

${ }^{33}$ Malin Pasaman, Interview, 28 Agustus 2017. 
One thing that became a common phenomenon in West Sumatra is that the matrilineal system of kinship of the Minangkabau society has allegedly caused problems to the continuity of any private institution. It is often difficult for any educational and religious foundations to survive more than one period of leadership. The question is, will such phenomenon also occur in a Sufi institution? Who replaces the position of the Sufi leader after his death? If his leadership position is bequeathed to his descendants, will it guarantee that it does not give raise to another problem? As stated by Ghazali, the matrilineal system of the Minangkabau society is not strong enough to bear inheritance of leadership. ${ }^{34}$ What happens in general is that leadership turns to his nephew, and not to his son. Of course this can cause any institution to be stuck (not to say decline and bankruptcy). With the exception of an institution that from the beginning was oriented as a "matrilineal that would automatically survive and be distributed hierarchically to his family. This is an institutional problem that many Sufi oders generally face in West Sumatra.

\section{Lineage of the Naqshabandi Order in Padang}

Followers of the Naqshabandi order believe that the order's teachings purely came from Allah, through the Angel of Jibril who handed it down to the Prophet Muhammad. Then Muhammad taught these teachings to his disciple, Abu Bakar, who would transmit them to the next generations, ${ }^{35}$ chain of transmission of which would reach Baha'uddin alNaqshbandy. Lineage of the Naqshabandi teachings can be traced all the way up to the Prophet Muhammad, down to Abu Bakar, Salman al-Farisi, Qāsim bin Muhammad bin Abu Bakar, Ja'far al-Shādiq, Abu Yazid AlBusthamī, Abu Hasan al-Kharaqanī, Abu Ali al-Farmadzī, Abu Ya'kub alHamdani, Abd al-Khaliq al-Ghujdawani, Arif al-Riwgari, Mahmud Najir Faghnawī, Azizan Ali Al-Ramitani, Muhammad Baba al-Sammasī, Amir Sayyid Kulal al-Bukhari, Muhammad Baha al-Din al-Naqshabandi. ${ }^{36}$ From al-Naqshabandi, they are transmitted to Muhammad Alauddin 'Athari, Ya'kub Jarekhi, Abdullah Ahra Risama Qandī, Muhammad Zahidi, Darwisi Muhammad, Muhammad Khaujki Amkannaki, Muhammad Baqi Billahi,

${ }^{34}$ Gazali, Interview, 3 September 2018.

35 Sri Mulyati, Tarekat-Tarekat Mktabarah di Indonesia (Jakarta: Kencana, 2004): 95; Hisyam Kabbani ar-Rabbani, Silsilah Rantai Emas I, trans. oleh Arief Hamdani dan et.al., vol. Vol. I (Jakarta: Rabbani Sudi Institute of Indonesia, t.t.): 19.

${ }^{36}$ Sri Mulyati, Tarekat-Tarekat Muktabarah di Indonesia (Jakarta: Kencana, 2004): 89 . 
Muhammad Faruqi Sarbidi, Muhammad Ma'sum, Shaifuddin, Nur Muhammad Bada Wani, Shamsuddin Habibullāh Janany, Abdullah Dahlawi, Khalid Jurdi, Abdullah Affandi, Sulaiman Qumi, and finally Sulaiman Zubdi. ${ }^{37}$

The above genealogy indicates that the Naqshbandi is a Sufi order that has its source of transmission from the Messenger of Allah, before it went through the golden chain of companions, Abu Bakar al-Shiddiq, Salman al-Farisi and Ja'far al-Shādiq. This lineage is slightly different from that of the other Sufi orders, which commonly refer their chain of transmission back to the Messenger of Allah, through the path of Ali bin Abi Thālib.

2. Leaders of the Naqshabandi Order in Pauh, Padang

The Naqshabandi Sufi order in Pauh, Padang has been led by a number of Sufi masters. They are as follows. The first is Syeikh Maulana Muhammad Thaib bin Ismail. ${ }^{38}$ Born in $1870 \mathrm{AD}$, his is the founder of the Naqshabandi in Padang. When he was 7 years old, he was invited by his father to study in Mecca. There, he studied with Sheikh Ahmad Khatib alMinangkabawi and Sheikh Sulaiman Zuhdi, known as Sheikh Jabal Kubis. After studying 25 years in Mecca, in $1905 \mathrm{AD}$, he returned to his hometown together with his wife. A year later, he founded the Naqshabandi in Pasar Baru, Padang. Syeikh Muhammad Thaib died in $1944 \mathrm{AD}$, and was buried beside the Surau Baru and Baitul Makmur. ${ }^{39}$

The second is Syeikh Angku Munir. After the death of Sheikh Muhammad Thaib, the Naqshabandi order was led by Sheikh Angku Munir. He died in $1985 \mathrm{AD}$ and was buried in Surau Baru and Baitul Makmur, right next to the cemetery of his predecessor, Sheikh Muhammad Thaib. The third is Syafri Malin Mudo. Born 72 years ago, he began studying the Naqshabandi teachings since 1975 AD. In 1986 AD, he obtained a diploma from Sheikh Angku Munir to disseminate the teachings of the Naqshbandi order. Today, Syafri Malin Mudo is the mursyid or leader of the Naqshabandi order in Padang.

37 Martin Van Bruinessen, Tarekat Naqsyabandiyah di Indonesia (Bandung: Miza, 1992): 48-9.

38 Rahmadi dan Abdul Razak, "Metode Penentuan Awal Bulan Qamariyah Jama'ah Thariqah Naqabandiyah Baru Pauh Kota Padang” (Research, Jambi, IAIN Sulthan Thaha Saifuddin, 2010): 36 .

${ }^{39}$ Munyar, Interview, 27 Agustus 2016. 
From this genealogy, it can be understood that the Naqshabandi Sufi order in Pauh, Padang holds a complete, strong and continuous chain of transmission(sanad), which goes all the way back to the noble companions of Abu Bakar and to the prophet Muhammad.

\section{Dimension of Cosmology in the Teachings of the Naqshabandi Order}

1. The Existence of Seven Layers of Heaven and Earth

In the Qur'an, the concept of cosmology is explained by Allah's affirmation of the creation of the heavens and the earth within six days. This is affirmed in seven verses of the Qur'an, among them is al-A'raf: 54, which reads, "Indeed, your Lord is Allah, who created the heavens and the earth in six days and then established Himself above the Throne". He also said in Qäf: 38, which says, "and verily We created the heavens and the earth and all between them in six days and nothing of pain or fatigue touched Us." Other detailed informations are mentioned in Yunus: 3, Hud: 7, al-Furqan: 59), asSajdah: 4, and al-Hadīd: 4.

The Qur'an gives a more detailed explanation on cosmology in Fushilat,: 2-12. This reads as follows.

"Say: 'Do you indeed disbelieve in Him who created the earth in two days and attribute equals to Him? That is the Rabb of the Worlds. And He placed on the earth firmly set mountains over its surface, and He blessed it and determined therein its [creatures'] sustenance in four days without distinction - for [the information] of those who ask. Then He directed Himself to the heaven while it was smoke and said to it and to the earth, "Come [into being], willingly or by compulsion." They said, "We have come willingly." And He completed them as seven heavens within two days and inspired in each heaven its command. And We adorned the nearest heaven with lamps and as protection. That is the determination of the Exalted in Might, the Knowing.

Ibnu Kathir mentions the description of Ibnu Abbas narrated by alBukhari in his Legitimate (Do you mean, Sahih? Or is this 'Legitimate' the title of Bukhari's work?), from Said bin Jubair, there was someone who asked Ibnu Abbas some verses which he thought are contradictory, among them are those concerning the creation of heavens and earth. This person asked, 
in Surah an-Nāzi'at (verses 27-30), Allah mentions that He created the heavens before creating the earth. While in Surah Fushilat (verses 9-12) Allah mentions that $\mathrm{He}$ created the earth before creating the heavens. The answer of Ibnu Abbas, Allah created the earth in two days, then He created the heavens. Then he went to heavens, then Allah perfected the heavens in the other two days. Then Allah perfected the earth). The form of perfecting the earth is He took out the springs from the earth, plants, Allah creates mountains, inanimate objects, highlands, and everything between heaven and earth, in two days. ${ }^{40}$ That is the meaning of Allah's word, "The earth is overlaid." While the word of Allah, "He created the earth in two days." The earth was created and everything within it in four days and created all the heavens in two days.

Thus, Allah created the earth for two days as the foundation, but the earth has not been there at that time. When the earth has been created, the sky was still smoke. This even shows different explanation with the big bang theory. It also shows that the earth is very meaningful in the universe. Unlike the system-heliocentric theory, which states that the earth is a random meaningless object. Then Allah created seven layers of heaven and its affairs within two days. Finally, Allah perfected the expanse of the earth by growing plants, strengthening them with mountains, running springs, creating valleys, rivers and other objects in the remaining two days, bringing the total to 6 Days.

In another verse, it is described the existence of seven heavens and seven layers of earth. It says, "It is Allah who has created seven heavens and of the earth, the like of them. [His] command descends among them so you may know that Allah is over all things competent and that Allah has encompassed all things in knowledge." (Al-Thalaq [65]: 12). In some legitimate hadith (divine quotes of the prophet), it is mentioned that the earth consists of seven layers, as narrated in Bukhari, from Sa'id bin Zaid, that the Messenger of Allah said: "Man zalama min al-ardl syai'an thawwaqahu min sab'i arädlinn: Whoever grabs the land of another person even if only one inch, then he will be imposed seven layers of the earth to him". It is mentioned in a hadith narrated by Ali bin Abdullah, that we got the information from Ibnu Uyainah from Ali bin al-Mubarak, from Yahya bin Abu Katsir from Abu Salamah, that Abu Salamah disputed the land with

${ }^{40}$ Adudin Alijaya, "Pendekatan Obyektif Dalam Tafsir Penciptaan Alam," Jurnal Burhan Vol. 18, no. 2 (2018). 
someone who later met Aisha, to tell him the matter. Aisyah said: "O Abu Salamah, stay away from the problems of the land, for the Messenger of Allah (Saw) once said, "Whoever does injustice even only one inch then he will be imposed to him from seven layers of heaven". From the information in the Qur'an and the Hadith, it is explained that both the heavens and the earth consist of seven layers. ${ }^{41}$

The Qur'an mentioning seven layers of sky and seven layers of earth $^{42}$ explain their existence in the rules of order, the order that inspires the pattern of balance for the universe. Such a balance makes both the heavens and the earth become beautiful, orderly and comforting to the creatures that live in and inhabit it. This will inspire the formula of life-building for human beings to achieve goodness in life, which is by the Sufis regarded as a prototype of ideal life harmony.

2. Sharia cosmology according to the Naqshbandi

The term sharia is found in the Qur'an, which is "Then We put you, [Muhammad], on an ordained way concerning the matter [of religion]; so follow it and do not follow the inclinations of those who do not know." (alJâthiyah: 18). "Sharia" is literally interpreted as the way to the watering hole for human beings and for livestock animals. ${ }^{43}$ From the semantic point of view, the Arabs use the word sharia to call the straight path that must be followed, or the path taken to obtain true and eternal life. This way, the term sharia(syart'atun) is a law made by Allah SWT which is established on the basis of faith and Islam, in the form of a set of laws about the formal deeds of human, which is governed by the revelation of the Qur'an and hadith or sunnah. ${ }^{44}$ Thus, sharia can be concluded as the provisions of Islamic religion, whether in the form of taklifi law [hukum taklifi], provisions of faith, and moral laws that regulate the implementation of Islamic teachings as well as possible.

In this context, Sharia is understood as a religious rule which Allah taught to His servants, which contains the teachings of faith, belief, law, ways

${ }^{41}$ Nur Awalia Wahyuni, “Aspek Eskatologis Dalam Naskah Ma'dan al-Ma'lum wa Al-Muzil Al-Gumum” (Thesis, Semarang, Universitas Diponegoro, 2019).

${ }^{42}$ Zaglul al-Najjar, Pembuktian Sains Dalam Sunnah (Jakarta: Amzah, 2006).

${ }^{43}$ Hamzah Tualeka Zn dan et.al, Akhlak Tasawuf(Surabaya: IAIN Sunan Ampel Press, 2011): 275.

${ }^{44}$ Hamzah Tualeka Zn dan et.al, Akhlak Tasawuf(Surabaya: IAIN Sunan Ampel Press, 2011): 275. 
of worship, how to behave well, ways of interacting, how to build a system of living together in the middle society for the sake of realizing the happiness of life in the world and the hereafter. The definition of Sharia includes teachings about faith in Allah, angels, messengers, the existence of supernatural-metaphysical reality, and good ways of life. Thus, the meaning of Sharia includes the implementation of the Faith, Islam and Ihsan.

The common understanding of sharia amongst most Muslims is different from that that is held by followers of the Naqshabandi order in Surau Baru and Baitul Makmur, (is this in Sauh?), Padang. According to the main teachings of the Naqshabandi, sharia is interpreted in such a way that involves the cosmological aspect. In our interview, Buya Syafri Malin Mudo, mursyid of the Naqshabandi order in Pauh, said that sharia, or Islamic law has close relationship with cosmological concepts, the conception of the earth which consist of seven layers. ${ }^{45}$ The seven layers of the earth are the properties revealed by the Qur'an as stated in the following verse, "He who has created the seven heavens in layers, you do not see in the creation of the Most Merciful any inconsistency. Then look again and again, do you see something that is not balanced?" (al-Mulk: 3 ). As well as stated in another verse, "It is Allah who has created seven heavens and of the earth, the like of them."(Al-Thalaq: 12).

In the first verse, it is mentioned that the number of sky is seven, while the shape is layered. This is the meaning of the word "thibaqan" which is found in the Qur'an and Arabic dictionaries. While in the second verse, it is emphasized that the earth resembles the sky "and so is the earth". The fact about the seven layers of the earth is also declared by the prophet Muhammad as follows, "Whoever grabs a span of land, then Allah will pile it with seven layers of the earth". ${ }^{46}$ The arguments in both the Qur'an and the sunnah explain that the balance structure of heaven and earth is layered (thibaqan).

The balance pattern of the earth and sky in seven layers is understood in the Naqshbandi as the meaning of the concept of sharia and haqiqa (the reality). Syafri Malin Mudo stated, "The sharia refers to the concept of fiqh (Islamic jurisprudence), which includes seven layers of rules that must be followed by humans, namely wajib (obligatory), haram

${ }^{45}$ Syafri Malin Mudo, Interview.

${ }^{46}$ Abu Abdullah Muhammad bin Ismail Al-Bukhari, Sahih al-Bukhari (Libanon: Dar Ibn Hazm, 2003). 
(forbidden), sunnah (favourable), makruh (unfavourable), mubah (permissible), sah (lawful), and batal (void)."47

The first. Obligatory means constantly or certainly. Yet, according to the term, it is something that is commanded by Allah and His Messenger to be performed by the mukallaf (muslims who already have religious legal obligations), the accomplishment of which will be rewarded by Allah, or otherwise recorded as sinful. According to the majority of Muslim scholars, "obligatory" is the same as fardhu, except in the pilgrimage. According to Hanafiyah, the fardhu is a demand to act in a definite form and the demands are stipulated by the qath'i (definitelly) proof and do not contain any doubt, whereas it must be stipulated by the proposition of zhanni (speculative) but still contains doubt. The scholars also divide the obligatory in terms of time implementation, that is obligatory muthlaq (total), or the obligations that are not bound by the time of its implementation, such as replacing the fasting of Ramadan that was missed and praying an oath fine. Another type of it is the so-called muaqqad obligatory (temporal), that is a kind of obligation whose implementation is determined within a certain time and is not legitimately performed outside the time specified. This obligatory type is divided into three parts, namely (i) muwassa' obligatory (expandable); a duty, it's an obligation that the time to do that exceeds the time to do that, such as the zuhr prayer; (ii) mudlayyaq obligatory(limited by time), that is the similar kind of obligation whose time of execution is limited within the time provided, ${ }^{48}$ such as fasting in Ramadan; and (iii) obligatory dzu syabhayn: this is the combination of muwassa 'and mudhayyaq obligatory, such as Hajj. In terms of its implementation, the obligatory is divided into two. They are, firstly, the 'aini obligatory or a personal obligation that no one else could possibly impose or because of another, such as fasting and prayer, and secondly, the kafa'i obligatory, or an obligation that is applied for the whole society, until it is done by an individual, or part of the society, such as the prayer for the death. ${ }^{49}$

The second is "haram", which means a legal status of an activity or an object, strictly prohibited by the law, with the consequences of being sinful for those who transgressed it. According to sharia, the legal status of

${ }^{47}$ Syafri Malin Mudo, Interview.

${ }^{48}$ Asmaul Fauziyah, "Studi Analisis Hisab Awal Waktu Salat Dalam Kitab Natijah al-Miqāt Karya Ahmad Dahlanal-Simarani” (Thesis, Semarang, IAIN Walisongo, 2012).

${ }^{49}$ Ahmad Syarwat, Shalat Berjama'ah (Jakarta: Rumah Fiqih Publishing, 2018). 
haram applies to prohibited acts, mentioned in both the Qur'an and Hadith, such as killing, stealing, adultery, drinking khamar, gambling and others. For the Sufi, unlawful acts include principle matters to be avoided as well as the first gateway to the maqam(level) to the Sufi's. Through the maqam tawbat, the Sufi necessitates the avoidance of unlawful deeds. Then, at the next level, the Sufi observes the principle of wara', that is an avoidance against actions or objects that are considered syubhat, in between permissible and forbidden. In A'mal al-Qulub's genealogy, Shaikh Shalih al-Munjid says that character of Sufis is evidenced by their abandonment of everything that makes doubts, eliminating the case of making disgrace and taking action with faith.

The third is sunnah. It has a variety of meaning. Hadith scholars interpret it as 'all that is left by the prophet Muhammad, be they words, deeds, khuluqiyah attributes, or his journey of life before and after being the prophet. Scholars of ushul fiqh (basic principle of Islamic jurisprudence) define the sunnah as anything that comes from the prophet Muhammad, ranging from words, deeds, to taqrir (symbolic acceptance). Then, according to Islamic law scholars, it refers to everything that is established from the prophet and is not part of fardhu (obligatory).$^{50}$

The fourth makruh. It refers toa legal status of an activity in which the activity is considered not preferable to do, but as such does not bear a sinful status to those who do that activity. According to Imam al-Zarkashi in his Bahrul Muhit, makruh is divided into four levels, namely (i) makruh of a haram lineance, as in al-Isra: 38; (ii) prohibition by light articles; (iii) makruh of 'better-to-leave-it-out' recommendation (tark al-aula); and (iv) makruh, disapproved deals with the matters that are considered to be arguments in theirs compassions, such as eating the flesh of a wild beast.

The fifth is mubah. The term mubah or al-ibahah comes from the word "baoh" and "būh" which means given permission, ${ }^{51}$ so mubah can be defined as deeds that is permissible to be done. In Fiqh, mubah is considered as a law that observes a neutral status of an object or action, be it implemented or ignored. It does not come with explanation of reward,

${ }^{50}$ Abu Muhammad Khusayn al-Bahiwy, Syarkhu Sunnah (Kairo: Dar al-Kutub Ilmiyah, nd): 12; Shafwan Adnan Dawudi, AL-Labab fi Ushul Fiqh (Kairo: Dar al-Qalam, nd): 199 .

${ }^{51}$ Khalil bin Ahmad al-Farahidi, Kitab al-'Ain (Beirut: Dar al-Maktabah, 1997): 204. 
torture, praise and blemish..$^{52}$ In both the Qur'an and Hadith, the word "ibāhah" is not used. Yet, it is of the opinion of fiqh scholars, who argue that many verses of the Qur'an elaborate the notion of ibāhah. For example, in al-Baqarah: 168, it is stated, "O mankind, eat from whatever is on earth (that is) lawful and good". This verse explains that an activity such as eating is considered as mubah. In other words, mubah is a legal status that observes an activity as one that dos not bear such a punishable consequence as wajib, haram, mustahab and makruh statutes do. In this case, individuals are free whether to do or to leave things considered mubah, such as eating and sleeping in a normal condition. With regard to ibadah, mubah has nothing do to with the law; since the legal status of an ibadah consists only four laws, they are wajib, mustahab, haram and makruh.

The sixth is sah. The term "sah" refers to a situation in which an act has a legal consequence in term of sharia law. It can be explained this way: if an obligatory ritual by a mukallaf is observed according to its required procedure, his ritual is valued sah, and he or she is considered fulfilling their obligation. In contrast, if the required procedure is unfulfilled, his ritualis considered not sah, or invalid. In activities of muamalah types, such as trading, and marriage, the procession in Islam after the ijab qabul was completed, the minister asked the witnesses wth the word "lawful". ${ }^{53}$

The seventh is batal. The word "batal" means that the act, deed, or contract that is observed has no legal consequence, because it does not fulfill the requirements. If it is about ibadah, the mukallaf is not free yet from burden and responsibility, even he has done it. It is also no legal consequences for the muamalah acts. If someone is not doing a prayer properly, he or sheis not free from an obligation of doing the prayer. In an activity of mu'amalah type like trading and marriage, if its requirements are not followed, the contract is considered broken or canceled, but it can be repeated until all requirements are fulfilled. ${ }^{54}$

${ }^{52}$ Saif al-Din Abi al-Hasan Ali bin Abi Ali bin Muhammad al-Amidi, Al-Ihkam fi Ushul al-Ahkam, Beirut: Dar al-Fikr, 1996 (Beirut: Darul Fikr, 1996).

${ }^{53}$ Abū Ishaq al-Syatibī, Al-Muwafaqāt fi Ushūl al-Syariah (Beirut: Dar al-Ma'rifah, 2003): 291-99.

${ }^{54}$ Ibid., 299. 
Related to the case of "sah and batip", there are two opinions: taklifi law and wadl'i law. The first opinion says that sah and batil as taklifi ${ }^{55}$ law because sah refers to the allowance of mukallah to make use of something, while batil refers to the ban of taking advantage. For example, if a trading contract is considered sah, the buyer can use the purchased items and vise versa. ${ }^{56}$ The second opinion (who says sah and batil as wadl'i) argues that sah and bathil related to the cause of something. According to sharia, an act is assumed to be sah as long as it has fulfilled the requirements; and it is assumed batil when the act has not fulfilled the requirements. Because of that, the status of sah and batil has nothing to do with doing, leaving or choosing between them, but related to the label given by God to the acts. The sah label is given to the activities fulfilling the requirements, including all the consequences appear, while the batil label isgiven to the activities unfulfilling the requirements and the consequences.

These seven concepts of shariah is a fundamental rule that must be obeyed by Muslims and especially by followers of the Naqshbandi order. For, wherever Muslims are located, they must obey these rules, in order to live in balance and with happiness. On the contrary, says Syafri Malin Mudo, Muslims who ignore these seven rules will destroy their lives and perish. ${ }^{57} \mathrm{In}$ accordance with the meaning of the seven rules of fiqh, it is not only interpreted within the viewpoint of fiqh, but also interpreted as a meaning that has been developed in society in general. This kind of understanding is seen to be closer to the concept of religious shariah with social-community culture, so as to create a pattern of life balance, similar to the balance of earth and the sky, both of which have seven layers. The author sees that the understanding developed by Syafri Malin Mudo based on a thought that human with all his activities and life is an integral part of nature. This is the model of understanding of cosmological Sharia developed by Syafri Malin Mudo through his Tariqat activities.

The concept of sharia is actually consisted of three categories, namely i'tiqadiyah, khuluqiyah, and 'ubudiyah. The first mentioned in the form of guidance and guidance to know Allah and the unseen nature that is not reached by the human senses or called ahkam syar'iyyah i'tiqadiyyah

${ }^{55}$ Ibn Umar al-Taftazani, Al-Talwih 'alā al-Tawzih (Kairo: Dar al-Kutub al-Arabia, 1327).

\footnotetext{
${ }^{56}$ al-Amidi, Al-Ihkam fi Ushul al-Ahkam, Beirut: Dar al-Fikr, 1996.

57 Syafri Malin Mudo, Interview.
} 
which became the subject of monotheism. Then syari'ah khuluqiyah is pointed to develop the potential of the good that exists in human to be a real respectable being who became the subject of knowledge of Sufism. And thirdly, the provisions governing the worship of Allah or the relationship of human with Allah, and the provisions governing the association and relationship between human and his neighbor and with his environment. At this point, the concept of sharia under the Naqshabandi is not only focused on the category of shari'a as understood by jurists, but reaching a broader and universal understanding.

3. Lathäif, the bodily internalizing pattern and the seven-layer symbolization of heaven

When asked about the concept of haqiqa, Buya Syafri Malin Mudo, the leader of the Naqshbandi in Pauh answered that haqiqa has many to do with the concept of the seven layers of heaven, as stated in the al-Mulk and al-Thalaq. Notice His words, "He who has created the heavens in seven layers, you do not see in the creation of the Most Merciful any inconsistency. Then look again and again, do you see something that is not balanced?" (AlMulk: 3).

The question is what is the relation between the nature and the seven layers of the sky? More specifically, Buya Syafri Malin Mudo argued that the seven-layered concept of the sky is the terminology known by the Sufis as the term Lathaiif. ${ }^{58}$ This word is the plural word of "Latîfah" which means subtlety, delicacy, and gentleness. Allah is Al-Latif, that is, the Most Gentle One, and He has given His gentleness to all ofthe so colled "Nur Muhammad" (the light of Muhammad). In this connection, Allah createshuman being with the virtue of seven subtle lathaif. To understand haqiqa as lathaiif is one of the understandings in many other meanings. In this context, haqiqa as an introduction to the Dzat (the esseance) of Allah can be explored through the stages of the lathaiif. Lathaif can also be attributed to human's internal bodies of brain, heart, spleen, liver, lungs and other internal parts of the physical body. Each latifah is associated with certain colors or certain parts of body, or certain realms. Furthermore, said Syafri Malin Mudo, the task of the Murshid is to enliven all the lathaif to the followers, so that they can be a reminiscent to Allah. Of course, the enlivening of all lathaif is done by reminiscing to Allah. which is the activity

${ }^{58}$ Ibid. 
of the Sufis. After going through this process, a salik (Sufi traveler) is said to have reached the level of perfection and become a perfect human being. ${ }^{59}$

A person who undergoes a lathäif ritual is obliged to purify his soul, knowledge and zikr (practice of remembering God), because all lathāif are "Nur" (light), and the "Nur" can only be purified with one that is also a Nur, that is knowledge and zikr. This means that the attainment of the essence of Allah can only be pursued through a pure level and stage, based on the inner holiness that begins in direct injection to the internal body parts of the human. At this point, it can be said that the implementation of lathaif rituals through the potential of spiritual knowledge and zikr can be done when the mental or psychological aspects are in stable condition. So that a lathaiifritual is a bodily internalization practice in order to bring closer the gentle souls of Sufi master to, and to be able to synergize with, the softness of Allah.

In relation to the practice of lathäif in Surau Baru and Baitul Makmur in Padang, the researchers looked directly at the internalizing efforts embedded in zikr activities of the Sufifollowers of the Naqshbandi order. In his observation, the researchers recognize that there is an effort among the Sufi travelers to include the sentences of zikr in ritual after the worship, which is practiced by "pressing" the fragments of "Lā ilāha illa Allăh", which includes seven parts of the body. This is the meaning of the seven-layered symbolism of the sky, that is implanted in the souls and cults of the Sufi followers. One of the followers of the Naqshabandi told the following:

"That the practice of lathäif emphasizes the spiritual reinforcement so that the soul is not disturbed by the whispers and disturbances of shaitan, or devils. The avoidance of these disruptions can provide a calmness in an effort to draw closer to Allah." 60

Thus, the lathaif practice of the Tariqat allegedly gives injection to the internal forces of human, such as the brain, heart, spleen, liver, lungs and other internal members of the body to synergize with the power of Nur of the Tenderness Owner. Stability of internal physical members is allegedly strong influence on the emergence of calm, optimism, relief, maturity of attitude, and confidence in daily activities.

\footnotetext{
${ }^{59} \mathrm{Ibid}$.

${ }^{60}$ Ja'far, Interview, 29 Juni 1016.
} 


\section{E. Conclusion}

From the discussion above, it can be concluded that the Naqshbandi order of Pauh in the city of Padang, West Sumatra presents typical teachings related to the exploration of the meaning of sharia, haqiqa and ma'rifat. For followers of the Naqshabandi in Pauh, the notion of sharia is not only understood as a conception of worshiping Allah through deeds, that is, by obeying His commands and avoiding His restrictions mentioned in the Qur'an and Sunnah, but also understood in its relationship with the cosmological and psycho-religious meanings. Sharia refers to the concept of fiqh which includes seven layers of rules, that must be followed by human, namely wajib (obligatory), haram (forbidden), sunnah (favourable), makruh (unfavourable), mubah (permissible), sah (lawful) and batal (void) as a contextualization of the seven layers of heaven and earth. These seventh concepts of fiqh are rules that must be obeyed by Muslims, and especially by followers of the Naqshbandi Sufi order in Pauh, the city of Padang. This is because, wherever Muslims are, they must obey these signs, in order to attain a balanced life, just as the seven balanced layers of both the heaven and earth. On the contrary, Muslims who ignore these rules will destroy their lives, and perish. The concept of the seven-layered sky and seven-layered earth is also internalized by the Sufis through the lathaif rituals In this regard, Allah has created human beings with the virtue of seven subtle lathäif, which are attributed to the internal parts of human's soul of the brain, heart, spleen, liver, lungs, and other internal parts of the body.

Thus, the cosmological dimension of the Naqshabandi Sufi teachings is enriched with psychological approaches, which helps the Sufi to approach Allah, which in turn directly brazes the mind, souls and emotions of the Sufi followers. The contextualization of this psycho-religious approach is discussed in the implementation of the Naqshbandi teachings in the form of muraqabah, i.e. the effort to see Allah, as well as the effort to present Allah in real life, well-known as musyāhadah. Both of these psychological approaches also provide direct reinforcement for the formation of the image of the Sufis in an odyssey before Allah in carrying out activities in everyday life. [.] 


\section{References}

Abidin, Zainal. "Membangun Harmoni Lewat Kebersamaan: Studi Kasus Dampak Sosial Penentuan Awal Ramadhan dan 1 Syawal Terhadap Umat Islam di Kota Padang." Harmoni, Vol. 9, no. 1 (2012): 5666.

Abu Abdullah Muhammad bin Ismail Al-Bukhari. Sahih al-Bukhari. Libanon: Dar Ibn Hazm, 2003.

Abū Ishaq al-Syatibī. Al-Muwafaqāt fi Ushūl al-Syariah. Beirut: Dar alMa'rifah, 2003.

Abu Muhammad Khusayn al-Bahiwy. Syarkhu Sunnah. Kairo: Dar al-Kutub Ilmiyah, nd.

Adlan Sanur Tarihoran. "Maliek Bulan Sebuah Tradisi Lokal Pengikut Tarekat Syattariyah di Koto Tuo Agam." ISLAM REALITAS: Journal of Islamic and Social Studies Vol. 1, no. 1 (2015).

Adudin Alijaya. "Pendekatan Obyektif Dalam Tafsir Penciptaan Alam." Jurnal Burhan Vol. 18, no. 2 (2018).

Afnida Nengsih. "Amalan Pengikut Tarekat Naqshabandiyah di Kecamatan Pauh Padang.” Research, IAIN Imam Bonjol, 1998.

Ahmad Syarwat. Shalat Berjama'ah. Jakarta: Rumah Fiqih Publishing, 2018. Amidi, Saif al-Din Abi al-Hasan Ali bin Abi Ali bin Muhammad al-. Al-Ihkam fi Ushul al-Ahkam, Beirut: Dar al-Fikr, 1996. Beirut: Darul Fikr, 1996.

Anton Bakker. Metodologi Penelitian Filsafat. Yogyakarta: Kanisius, 1995.

Ashma Rimadany. "Comparative Study Between Naqsabandiyah and Syattariyah Congregations in Determining the Beginning of Islamic Lunar Month in West Sumatera Province.” Thesis, UIN Walisongo, 2016.

Asmaul Fauziyah. "Studi Analisis Hisab Awal Waktu Salat Dalam Kitab Natijah al-Miqāt Karya Ahmad Dahlanal-Simarani.” Thesis, IAIN Walisongo, 2012.

Bruinessen, Martin Van. Tarekat Naqsyabandiyah di Indonesia. Bandung: Mizan, 1992.

Burhanuddin, dan Nur Latifah. "Peran Pendidikan Tarekat Qadiriyah wa Naqsyabandiyah.” Jurnal Tatsqif Vol. 15, no. 2 (2017): 223-41. 
Dedy Wahyudin. "Memahami Bahasa Sufistik Kaum Salikin: Studi Kasus Pengamal Tarekat Qadiriyah Wa Naqsyabandiyah di Pondok Pesantren Darussalam Bermi Lombok Barat Nusa Tenggara Barat." El-Tsaqafah: Jurnal Jurusan PBA Vol. 15, no. 2 (2016): 113-23.

Duski Samad. "Tradisionalisme Islam di Tengah Modernisme: Kajian Tentang Kontiniutas, Perubahan dan Dinamika Tarekat di Minangkabau." Disertation, UIN Syarif Hidayatullah Jakarta, 2003.

E. L. Wright. What is The Evidence for The Big Bang? UCLA: Devision of Astronomy and Astrophysics, 2009.

Firdaus, et.al. Sentra-Sentra Tarekat di Minangkabau, 2000.

Gazali. Interview, 3 September 2018.

Hamzah Tualeka Zn, dan et.al. Akhlak Tasawuf. Surabaya: IAIN Sunan Ampel Press, 2011.

Hisyam Kabbani ar-Rabbani. Silsilah Rantai Emas I. Diterjemahkan oleh Arief Hamdani dan et.al. Vol. Vol. I. Jakarta: Rabbani Sudi Institute of Indonesia, t.t.

I Gusti Made Widya Sena. "Konsep Kosmologi Dalam Perspektif Agama Budha." Vidya Samhita Jurnal Penelitian 110, no. 1 (2015): 11024.

Ibn Umar al-Taftazani. Al-Talwih 'alā al-Tawzih. Kairo: Dar al-Kutub alArabia, 1327.

J. Edward Wright. The Early History of Heaven. USA: Oxford University Press, 2002.

Ja'far. Interview, 29 Juni 1016.

Jonathan Keohane. "Bing Bang, Nasa's Imagine the Universe: Ask an Astrophysicist," t.t. Diakses 3 September 2017.

Katsuhiko Sato. "First-order phase transition of a vacuum and the expansion of the Universe." Monthly Notices of the Royal Astronomical Society 195, no. 3 (1981): 467-79.

Khalil bin Ahmad al-Farahidi. Kitab al-'Ain. Beirut: Dar al-Maktabah, 1997. Because of You. "Konsep Penciptaan Alam Semesta Menurut Hindu, Islam, Kristen Dan Konsep Modern,” 30 April 2009. https://www.narayanasmrti.com/2009/04/konsep-penciptaanalam-semesta-hindu-islam-kristen-dan-secara-ilmiah/.

Louis Kattsoff. Pengantar Filsafat. Yogyakarta: Tiara Wacana, 1986. 
Malin Pasaman. Interview, 28 Agustus 2017.

Moh. Sakir. "Genealogi Tarekat Pesantren Sebagai Basis Pembentukan Kesalehan.” Manarul Qur'an: Jurnal Ilmiah Studi Islam Vol. 18, no. 2 (2018): 64-79.

Moh. Taufiq. "Pola Pendidikan Berbasis Tareqat Qadiriyah wa Naqshabandiyah di Pondok Pesantren Assalafi al-Fitrah Surabaya.” Jurnal Pendidikan Agama Islam VOl. 5, no. 1 (2017): 138-60.

Munyar. Interview, 27 Agustus 2016.

Nur Awalia Wahyuni. “Aspek Eskatologis Dalam Naskah Ma'dan al-Ma'lum wa Al-Muzil Al-Gumum.” Thesis, Universitas Diponegoro, 2019.

Paul Edward. The encyclopedia of philosophy. Vol. 2. New York, 1967.

Rahmadi, dan Abdul Razak. "Metode Penentuan Awal Bulan Qamariyah Jama'ah Thariqah Naqabandiyah Baru Pauh Kota Padang.” Research, IAIN Sulthan Thaha Saifuddin, 2010.

Runes D. Dagobert. Dictionary of Philosophy. Tottawa: Litle Field Adams \& Co., 1977.

Said, Fuad. Hakekat Tarekat Naqshabandiyah. Jakarta: Pustaka al-Husna, 1994.

Sean M. Carroll. Dark Matter, Dark Energy: The Dark Side of the Universe, Part 1 \& 2. The Teaching Company, 2007.

Shafwan Adnan Dawudi. AL-Labab fi Ushul Fiqh. Kairo: Dar al-Qalam, nd.

Sri Mulyati. Tarekat-Tarekat Muktabarah di Indonesia. Jakarta: Kencana, 2004.

Susanto, Faisal Bahar. “Tareqat Qadiriyah Naqshabandiyah: Tinjauan Historis dan Educatif Tarekat Qadiriyah Naqshabandiyah di Desa Balak.” Ph.D Thesis, Universitas Muhammadiyah Surakarta, 2006.

Syafri Malin Mudo. Interview, 19 Juni 2017.

Syarif. "Dari Masīrat al-Hikam Hingga Kayfiyat al-Ṭarīqat: Pergeseran Ajaran tarekat Naqshabandiyah di Sumatera Barat.” PENAMAS Vol. 28, no. 1 (2015).

Yulizal Yunus. "Kajian Syair Apolegetik Pembela Tarekat Naqsyabandiyah Syaikh Bayang.” Research, IAIN Imam Bonjol, 1999.

Zaglul al-Najjar. Pembuktian Sains Dalam Sunnah. Jakarta: Amzah, 2006. 